\title{
Technical Development of Design \& Fabrication of an Unmanned Aerial Vehicle
}

\author{
Md. Fazlay Rabbey ${ }^{1}$, Easir Arafat Papon ${ }^{2}$, Anik Mahmood Rumi ${ }^{3}$, \\ Hafez Md. Monerujjaman ${ }^{4}$, Farhan Hasan Nuri $^{5}$ \\ 1,2,3,4,5 (Aeronautical Engineering Department, Military Institute of Science \& Technology, Bangladesh)
}

\begin{abstract}
UAV (Unmanned Aerial Vehicle) is an air vehicle which is largely used for surveillance, monitoring, reconnaissance, data relay, and data collection or to enter the area which is not safe for human i.e. flood affected or virus affected area. This paper represents the unique design of such an UAV which designed at MILITARY INSTITUTE OF SCIENCE \& TECHNOLOGY to participate in an international competition SAE Aero Design West-2013. As per competition requirement empty weight of the UAV must be less than $2 \mathrm{lb}$ and must fly with payload as heavy as possible for good scoring. Initially, the model of the UAV was tested in wind tunnel and the test data showed that the model aircraft performance was capable enough for flying and covering an area specified in the competition. Subsequently, an actual aircraft was fabricated of that model and flight tested which proved the match with theoretical, statistical and experimental data that was obtained from wind tunnel test, wing tip test, tensile test of manufacturing material and CFD (Computational Fluid Dynamics) flow simulation over the aerofoil.
\end{abstract}

Keywords: Unmanned aerial vehicle (UAV), NACA 4412, unique design UAV.

\section{INTRODUCTION}

Birds can fly in sky due to their inherent characteristics. They are the dominant in the sky. It is human characteristics to dominate or rule over other. So they tried their best to fly in sky from dawn of civilization. And they got it through the success of Wright brother's in 1903. Subsequently many modernization and invention had done through $19^{\text {th }}$ century and now a day's fly without pilot is one of the most important topics of study worldwide for national, international, military purposes under the banner of Unmanned Aerial Vehicle (UAV). Present paper discusses the systematic design, data analysis, different property calculations and then manufacturing of such type of UAV with low cost which successfully flew in the sky in USA [as a part of NASA-SAE competition at California 12-14 April 2013]. The project team secured $19^{\text {th }}$ position in this contest.

\section{GoAl OF THE PROJECT}

The goal of the project was to develop and exhibit a practical method of building a unique design UAV and also take off, cruise and land it within the specified area given in the competition. This goal was being met by engineering basics such as aerodynamics, propulsion, structural analysis, control system etc. The UAV was launched by hand without the use of a runway for takeoff. Detail design was conducted using SolidWorks software and then different parts of the prototype were manufactured from XPS foam, depron foam and other materials using heat cutter machine. Ultimately, an airworthy aircraft was to be fabricated to meet competition requirements.

\section{CONCEPTUAL DESIGN}

The objective of conceptual design is to design an UAV based on the analysis of mission goals, requirements and the design constraints set out in the competition. This was done through step by step analysis of seven pivot points suggested by Raymer[7]. The expected result from this was to obtain a high performance design that maximizes the overall flight score in the competition:

Final Flight Score $=\mathrm{i} \times($ Best Flight Score $)$

Where, $\mathrm{i}=1+\left(\mathrm{A}_{0}-40 \%\right) \times .25$

$$
\& \mathrm{~A}_{0}=\frac{\text { Successful Flight }}{\text { Successful Flight }+ \text { Missed Flight }}
$$

Again, Flight Score $=(2-$ EW $)$ x PF x 120

Where EW = Empty Weight in pounds, and 


$$
\& \mathrm{PF}=\frac{\text { Payload Weight }+ \text { Empty Weight }}{\text { Payl }}
$$

Using the formula it was ensured that for good performance empty weight was to be as small as possible whereas carrying payload should be large. So, the aircraft configurations were selected in such a way that the empty weight was small and it could fly with heavy payload. The aircraft configurations were selected based on the following criteria [6]:

a) The conventional configuration was chosen over the flying wing, biplane etc. due to its easy of manufacturing, less interference drag than biplane, high maneuverability, lightweight, flexibility of design and good L/D with much more reliability.

b) High wing aircraft has advantages over low and mid wing aircraft. Because high wing aircraft has the increased lifting surface area at the centre of the wing where in other designs the wing attached to the fuselage this lifting surface is lost. In high wing less Interference drag exists between the wing and fuselage.

c) Single tractor configuration was selected over the single pusher, double tractor and push-pull configuration because it faces undisturbed flow while the pusher faces disturbed and vortex flow over the body and wing respectively. For the single tractor also results in the overall lighter aircraft.

d) Conventional tail is selected over V-Tail, T-Tail, Tailless delta, Cruciform tail because it is easy to install and provides robust and sufficient stability to the aircraft while in T-Tail weight penalty increased and in V-Tail control authority of pitch and yaw is reduced.

The concept reflects the following preliminary design [6]:

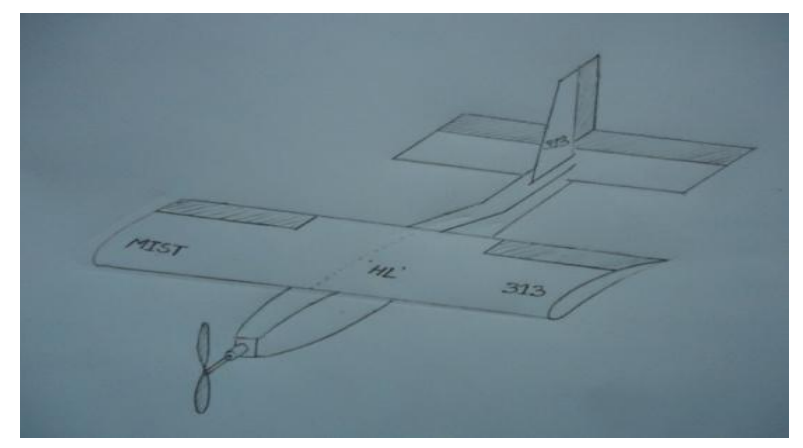

Fig. 1: preliminary design by hand sketching

\section{DETAIL DESIGN OVERVIEW}

Before doing main design the thing kept in mind was the given restrictions in the competition. Every year SAE hosts a competition to design, construct and fly 3 types of aircraft i.e. micro class, advance class and regular class. The team participated in micro class aircraft competition. Restrictions in this class were:

a) No lighter-than-air or rotary wing aircraft.

b) Maximum dimension of any parts can be 24 inch because all components for operation of the aircraft must be put into a padded foam carrying case and inside dimension of Carrying Case should not exceed 24 inches by 18 inches by 8 inches ( $24 " \times 18 " \times 8 ")$.

c) The use of lead in any portion of the aircraft (payload included) is strictly prohibited.

d) Micro class aircraft can use electric motor only.

e) Aircraft must be capable of carrying and fully enclosing a rectangular block measuring 2 inches by 2 inches by 5 inches (minimum size). The payload must consist of a support assembly and payload plates.

f) The aircraft must be capable of flight worthy without carrying a payload.

g) The aircraft must be able to take-off, complete a circuit and then safe land.

h) The UAV must be an empty weight of less than $2 \mathrm{lbs}$.

i) Maximum three (3) minutes to accomplish a successful takeoff.

j) Maximum three (3) minutes to assembly the aircraft from the padded foam carrying case in three (3) minutes by two (2) people.

By keeping in mind restrictions the detail design [6] was conducted in SolidWorks and its basic layout is shown in the following: 


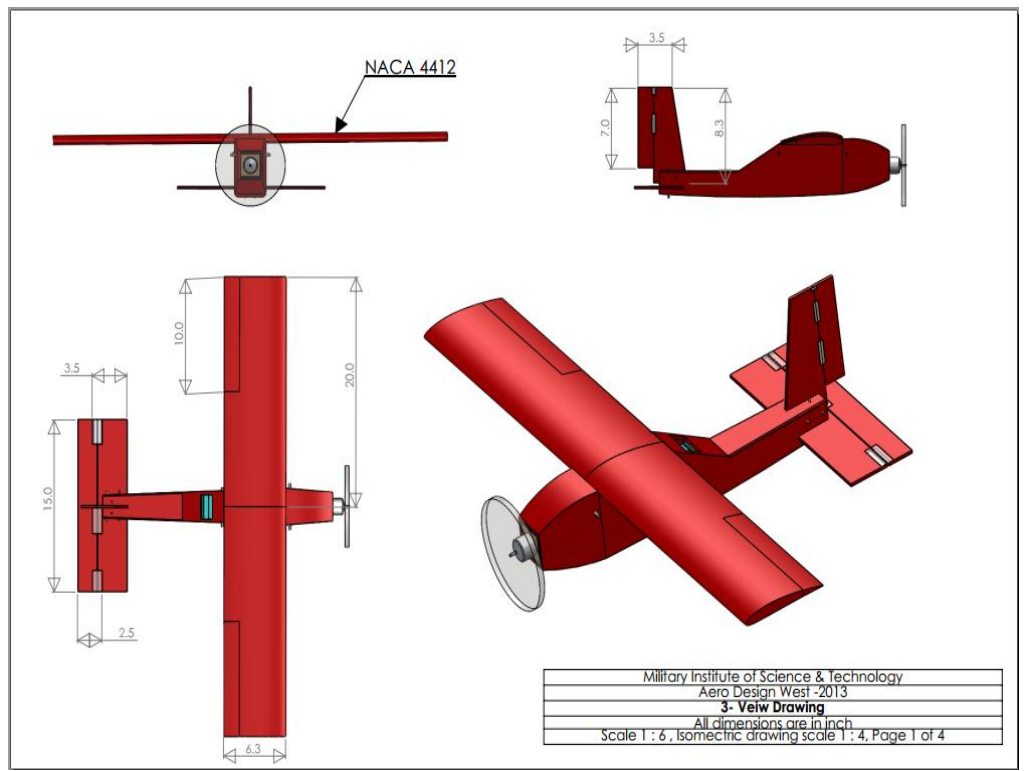

Fig. 2: 3D model of the UAV

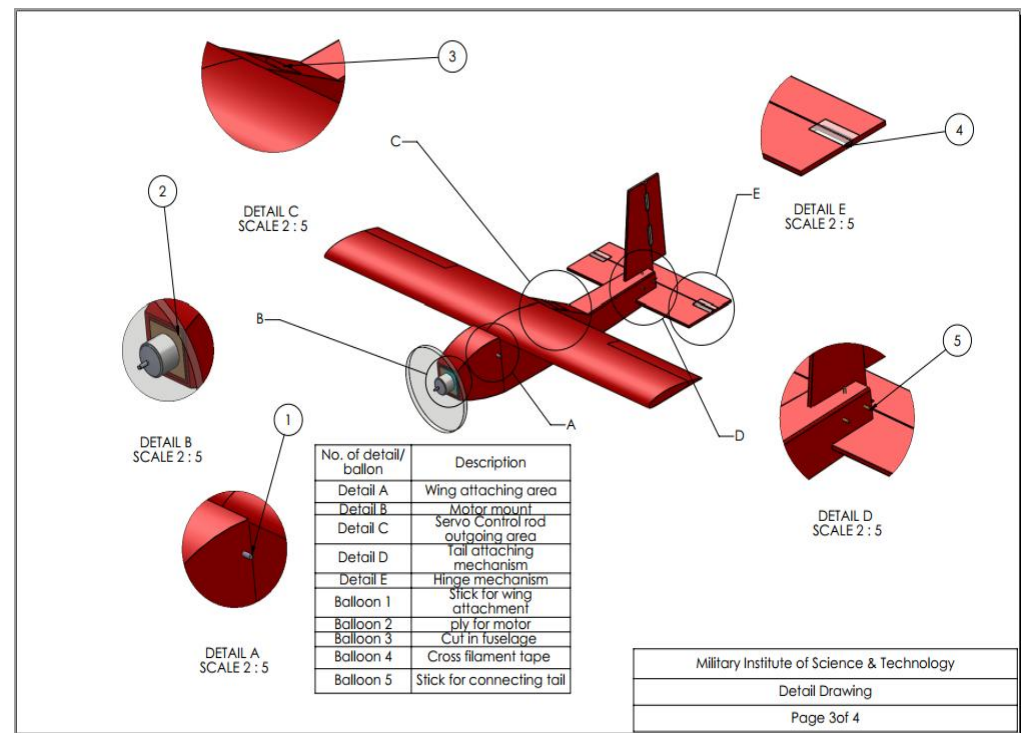

Fig. 3: joint mechanism and attaching area of different parts

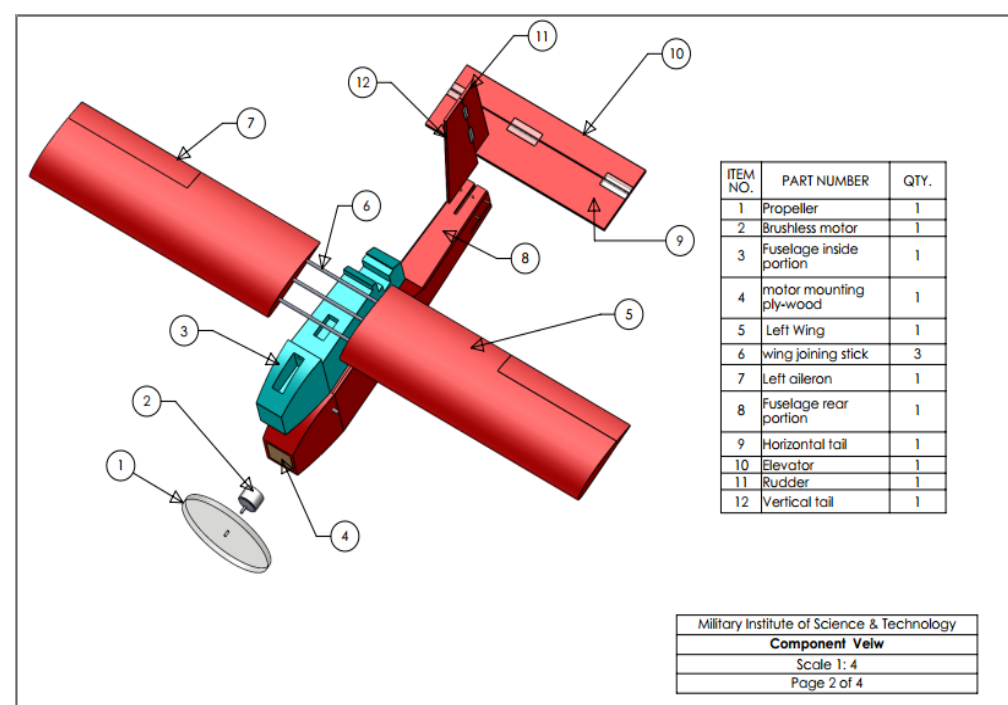

Fig. 4: all internal and external components of the UAV 


\section{DETAIL DIMENSIONS}

The designed UAV was performed a better aerodynamic efficiency when the flow passes through over it during flight. The detail dimension of the UAV is as follows:

Table 1: Detail dimensions

\begin{tabular}{|c|c|c|c|c|c|}
\hline \multicolumn{2}{|c|}{ DETAIL DIMENSION } & \multicolumn{2}{|c|}{ HORIZONTAL STABILIZER } & \multicolumn{2}{|c|}{ AILERON } \\
\hline & & Airfoil & Flat plate & Span & 10 in \\
\hline \multicolumn{2}{|c|}{ WING } & Span & 15 in & $\%$ of chord & $25 \%$ \\
\hline Span & 40 in & Chord & 5 in & Max. $\delta_{a}$ & $17.5^{\circ}$ \\
\hline Chord & 6.3 in & Area & $75 \mathrm{in}^{2}$ & RUDD & \\
\hline Aspect ratio & 6.35 & Incidence & $2^{\circ}$ & Span & 7 in \\
\hline Taper ratio & 1 & Thickness & 0.2 in & Thickness & 0.2 in \\
\hline Wing area & $252 \mathrm{in}^{2}$ & \multicolumn{2}{|c|}{ VERTICAL STABILIZER } & $\%$ of tip chord & $45.5 \%$ \\
\hline Airfoil & NACA 4412 & Airfoil & Flat plate & Max. $\delta_{\mathrm{r}}$ & $17.5^{\circ}$ \\
\hline $\begin{array}{c}\text { Static margin } \\
\text { (without payload) }\end{array}$ & $26.5 \%$ & Root Chord & 5 in & \multicolumn{2}{|c|}{ ELEVATOR } \\
\hline $\begin{array}{l}\text { Static margin (with } \\
\text { payload) }\end{array}$ & $12.2 \%$ & Tip chord & 3.45 in & Span & 15 in \\
\hline Incidence & $3^{\circ}$ & Span & 8.31 in & $\%$ of chord & $40 \%$ \\
\hline \multicolumn{2}{|c|}{ FUSELAGE } & Taper ratio & 0.69 & Max. $\delta_{\mathrm{e}}($ down $)$ & $17.5^{\circ}$ \\
\hline Length & 23.22 in & Thickness & 0.2 in & Max. $\delta_{\mathrm{e}}(\mathrm{up})$ & $-17.5^{\circ}$ \\
\hline Max Width & 3.2 in & Mean Chord & 4.27 in & Thickness & 0.2 in \\
\hline
\end{tabular}

\section{CALCULATIONS} calculation.

This step includes3D drag analyses, performance analysis, weight build up analysis \& stability margin

\subsection{DRAG ANALYSIS INCLUDING 3-D DRAG EFFECT}

The drag effects was analyzed through commercially available software like CFD, JAVAFOIL. By analyzing different test results from these softwares, wind tunnel and historical data [11][1][4] the final finding was NACA 4412 aerofoil to meet the desired objectives. The aircraft drag polar was determined by following [5]: $\mathrm{C}_{\mathrm{D}}=\mathrm{C}_{\mathrm{D}(\min )}+\mathrm{K}^{\prime} \mathrm{C}_{\mathrm{L}}{ }^{2}+\mathrm{K}^{\prime}\left(\mathrm{C}_{\mathrm{L}}-\mathrm{C}_{\mathrm{L}(\min )}\right)^{2}$

Table 2: Ambient flight condition

\begin{tabular}{|c|c|}
\hline \multicolumn{2}{|c|}{ Ambient flight condition } \\
\hline Flight speed (Take-off) & $10.72 \mathrm{~ms}^{-1}$ \\
\hline Air density at sea level & $1.225 \mathrm{kgm}^{-3}$ \\
\hline Air pressure at sea level & $1 \mathrm{~atm}$ \\
\hline Sea level temperature & $15^{\circ} \mathrm{C}$ \\
\hline Kinematic viscosity of air, $v$ & $1.4607 \times 10^{-5} \mathrm{~m}^{2} / \mathrm{s}$ \\
\hline Gas constant, R & $287 \mathrm{Jg}^{-1} 1 \mathrm{~K}^{-1}$ \\
\hline Specific heat ratio, $\gamma$ & 1.4 \\
\hline
\end{tabular}

For laminar flow: $\mathrm{C}_{\mathrm{f},(\mathrm{lam})}=1.328 /(\mathrm{Re})^{0.5}$

When the BL is tending to turbulent: $C_{\mathrm{f},(\mathrm{tur})}=0.455 /\left(\left(\log _{10} \operatorname{Re}\right)^{2.58}+\left(1+0.144 \mathrm{M}^{2}\right)^{0.65}\right)$

Table 3: Area \& length of different parts

\begin{tabular}{|c|c|c|c|}
\hline Parts & Planform area, $\mathrm{S}_{\text {Ref }}\left(\mathrm{in}^{2}\right)$ & Wetted area, $\mathrm{S}_{\text {Wet }}\left(\mathrm{in}^{2}\right)$ & Reference length (in) \\
\hline Fuselage & 60.47 & 274.67 & 23.22 \\
\hline Horizontal Tail & 75 & 150 & $5(\mathrm{MAC})$ \\
\hline Wing & 252 & 504 & $6.3(\mathrm{MAC})$ \\
\hline Vertical Tail & 0 & 67.3 & $3.17(\mathrm{MAC})$ \\
\hline
\end{tabular}

Fuselage: $\mathrm{Re}=\mathrm{VL} / v=432806$, assume BL is turbulent.

Mach number: $\mathrm{M}=\mathrm{V} /(\gamma \mathrm{RT})^{0.5}=0.0315$

Co-efficient of friction: $C_{f,(t u r b)}=\left\{0.455 /\left(\log _{10} R e\right)^{2.58}\right\}-(1700 / R e)=1.33 \times 10^{-3}$

For the aircraft: $\mathrm{FR}=$ Fuselage fineness ratio $=$ Fuselage length/width $=7.26$.

Fuselage form factor: $\mathrm{FF}_{\mathrm{F}}=1+60 /(\mathrm{FR})^{3}+0.0025 \mathrm{FR}=1.1749$

So, for fuselage: $\mathrm{C}_{\mathrm{D} \min }=\mathrm{FF}_{\mathrm{F}} \mathrm{C}_{\mathrm{f}} \mathrm{S}_{\mathrm{Wet}} / \mathrm{S}_{\mathrm{Ref}}=0.0071$

Wing: For wing, $\mathrm{Re}=\mathrm{VC} / v=117413$.

Wing form factor: $\mathrm{FF}_{\mathrm{W}}=\left[1+\mathrm{L}(\mathrm{t} / \mathrm{c})+100(\mathrm{t} / \mathrm{c})^{4}\right] \mathrm{R}$, Where $\mathrm{L}$ is the airfoil thickness location parameter $(\mathrm{L}=1.2$ for the max $t / c$ located at $\geq 0.3 \mathrm{c}$ and $\mathrm{L}=2.0$ for the $\max t / \mathrm{c}<0.3 \mathrm{c}$ ) and $\mathrm{R}$ is the lifting surface correlation parameter. Thus $\mathrm{L}=1.2$. For a low speed, unswept wing $\mathrm{R}$ is approximately 1.05 . 
Since a wing $\mathrm{Re}=117413$ could be treated as laminar.

As the BL is laminar, the wing: $\mathrm{C}_{\mathrm{f}}=1.328 /(\mathrm{Re})^{0.5}=0.00388$.

So wing form factor: $\mathrm{FF}_{\mathrm{W}}=\left[1+\mathrm{L}(\mathrm{t} / \mathrm{c})+100(\mathrm{t} / \mathrm{c})^{4}\right] \mathrm{R}=1.223$

and minimum drag coefficient: $\mathrm{C}_{\mathrm{D}(\min )}=\mathrm{FF}_{\mathrm{W}} \mathrm{C}_{\mathrm{f}} \mathrm{S}_{\mathrm{Wet}} / \mathrm{S}_{\mathrm{Ref}}=0.0095$

Horizontal Tail: For horizontal tail: $\mathrm{Re}=\mathrm{VC}_{\mathrm{HT}} / v=93185$. Therefore we'll assume the $\mathrm{BL}$ is laminar.

$\mathrm{C}_{\mathrm{f}}=1.328 /(\operatorname{Re})^{0.5}=4.35 \times 10^{-3}$.

Form factor: $\mathrm{FF}_{\mathrm{HT}}=\left[1+\mathrm{L}(\mathrm{t} / \mathrm{c})+100(\mathrm{t} / \mathrm{c})^{4}\right] \mathrm{R}=1.1$

and minimum drag coefficient: $\mathrm{C}_{\mathrm{D}(\min )}=\mathrm{FF}_{\mathrm{W}} \mathrm{C}_{\mathrm{f}} \mathrm{S}_{\mathrm{Wet}} / \mathrm{S}_{\mathrm{Ref}}=0.0096$

Vertical Tail: For vertical tail: $\mathrm{Re}=\mathrm{VC}_{\mathrm{VT}(\mathrm{MAC})} / v=59042$. Therefore assume the $\mathrm{BL}$ is laminar.

$\mathrm{FF}_{\mathrm{HT}}=\left[1+\mathrm{L}(\mathrm{t} / \mathrm{c})+100(\mathrm{t} / \mathrm{c})^{4}\right] \mathrm{R}=1.127$

$\mathrm{C}_{\mathrm{f}}=1.328 /(\mathrm{Re})^{0.5}=5.47 \times 10^{-3}$

$\mathrm{C}_{\mathrm{D}(\min )}=\mathrm{FF}_{\mathrm{W}} \mathrm{C}_{\mathrm{f}} \mathrm{S}_{\mathrm{Wet}} / \mathrm{S}_{\mathrm{ref}}=0.0123$

Total $\mathrm{C}_{\mathrm{D}(\min )}$ : The total $\mathrm{C}_{\mathrm{D}(\min )}$ is the sum of all the components. Thus the total model $\mathrm{C}_{\mathrm{D}(\min )}=0.0385$ based upon a wing reference area of $252 \mathrm{in}^{2}$

Total Drag Expression: Assuming a span effectiveness factor e $=0.95$ gives an induced drag factor $\mathrm{K}^{\prime}=1 /(\pi$ $\mathrm{AR}$ e) $=0.0528$. Assuming the viscous drag factor $\mathrm{K} ",=0.0211$ is $40 \%$ of the induced drag factor [10]. The section drag polar data was determined to find out using JAVAFOIL. The determined $\mathrm{C}_{\mathrm{L}(\mathrm{min})}=0.4$. So, the total drag expression is:

$\mathrm{C}_{\mathrm{D}}=0.0385+0.0528 \mathrm{C}_{\mathrm{L}}^{2}+0.0211\left(\mathrm{C}_{\mathrm{L}}-0.4\right)^{2}$

The model drag polar is shown on the following Fig. 5:

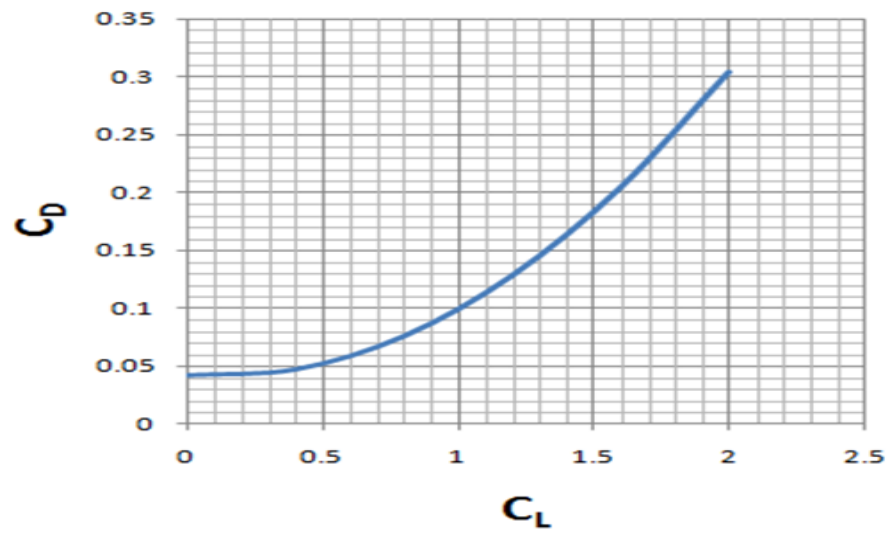

Fig. 5: drag polar

\subsection{WEIGHT ESTIMATION}

As a first approximation from historical data, empty weight fractions, $\mathrm{W}_{\mathrm{e}} / \mathrm{W}_{0}=0.56$ [5]

Again, Payload weight, $\mathrm{W}_{\mathrm{P}}=1.1 \mathrm{lb}$. But, gross weight: $\mathrm{W}_{0}=\mathrm{W}_{\mathrm{P}}+\mathrm{W}_{\mathrm{e}}$

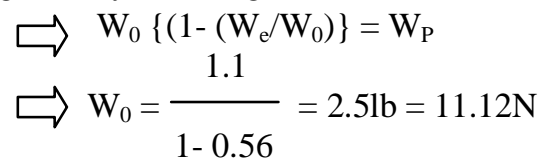

6.3 $\mathrm{V}_{\text {STALL }} \& \mathrm{C}_{\mathrm{LT} / \mathrm{o}}$ ESTIMATION

For the UAV high A.R. wing was chosen with wing span, $b=40$ in; chord, $c=6.3$ in

So, A.R. $=6.35$; Wing Area, $\mathrm{S}=252 \mathrm{in}^{2}=0.162 \mathrm{~m}^{2}$ Again, the used was Aerofoil NACA 4412 for which the $\mathrm{C}_{\mathrm{Lmax}}=1.22$ (from wind tunnel testing)

But, wing loading [5]: W/S $=0.5 \times$ air density $\times \mathrm{V}_{\text {stall }}^{2} \times \mathrm{C}_{\mathrm{Lmax}}$

So, stall velocity, $\mathrm{V}_{\text {stall }}=9.5 \mathrm{~m} / \mathrm{s}=31.13 \mathrm{ft} / \mathrm{s}$

Again, take-off lift-coefficient: $\mathrm{C}_{\mathrm{LT} / \mathrm{O}}=\mathrm{C}_{\mathrm{Lmax}} / 1.21=1.22 / 1.21=1.01$

6.4 ESTIMATING PERFORMANCE

The UAV weight with payload, $\mathrm{W}=11.16 \mathrm{~N}$ (From Weight build-Up Section).

Again, $\mathrm{C}_{\mathrm{LT} / \mathrm{o}}=1.01$. So, take-off velocity: $\mathrm{V}_{\mathrm{TO}}=\left[2 \mathrm{~W} /\left(\mathrm{S} \rho \mathrm{C}_{\mathrm{LT} / \mathrm{o}}\right)\right]^{1 / 2}=10.72 \mathrm{~m} / \mathrm{s}$

Table 4: Propulsion summary

\begin{tabular}{|c|c|}
\hline KV parameter of the motor & $1200 \mathrm{Kv}$ \\
\hline \hline Battery voltage & $11.1 \mathrm{~V}$ \\
\hline \hline Propeller Diameter $\times$ Pitch & $7 \times 6$ in \\
\hline \hline Power & $250 \mathrm{~W}$ \\
\hline
\end{tabular}


Propeller RPM: RPM=KV $\times$ Volt=13320rev $/ \mathrm{min}=1395 \mathrm{rad} / \mathrm{s}$

Assuming, $\eta_{\text {prop }}=0.8$. But, pitch velocity: $V_{\text {pitch }}=R P M \times$ pitch $\times \eta_{\text {prop }}=170 \mathrm{~m} / \mathrm{s}$

Thrust:T=Power $/ \mathrm{V}_{\text {pitch }}=250 / 170=1.47 \mathrm{~N}$

Thrust/Weight (with payload) Ratio $=0.132$

6.5 TAKEOFF DISTANCE ESTIMATION

We Know, Roll distance after launching [5]:

$$
\mathrm{S}_{\mathrm{g}}=\frac{1.21(\mathrm{~W} / \mathrm{S})}{\mathrm{g} \times \text { air density } \times\left(\mathrm{C}_{\mathrm{L}}\right)_{\max }(\mathrm{T} / \mathrm{W})}=44 \mathrm{~m}=144 \mathrm{ft}
$$

But, turn radius [5]:

$$
\mathrm{R}=\frac{6.96\left(\mathrm{~V}_{\text {stall }}\right)^{2}}{\mathrm{~g}}=64 \mathrm{~m}=210 \mathrm{ft}
$$

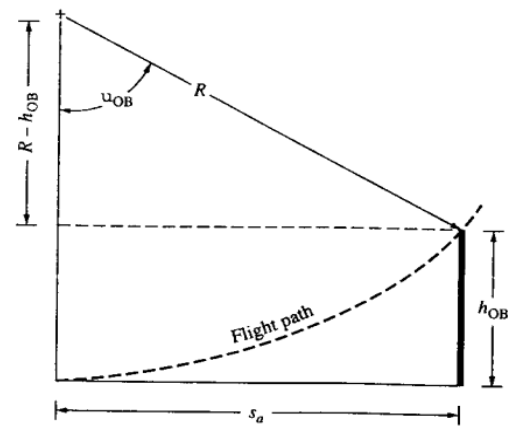

Fig. 6: during airborne [5]

Again, from the above Fig. 6: R (1-cos $\left.\mathrm{u}_{\mathrm{OB}}\right)=\mathrm{h}_{\mathrm{OB}}$

$\&$ if height of obstacle, $\mathrm{h}_{\mathrm{OB}}=35 \mathrm{ft}$

So, $\mathrm{u}_{\mathrm{OB}}=33.56^{0}$

So, Airborne Distance: $\mathrm{S}_{\mathrm{a}}=\mathrm{R} \sin \mathrm{u}_{\mathrm{OB}}=210 \sin 33.56^{\circ}=116 \mathrm{ft}$

Total Take-off Distance: $\mathrm{S}=\mathrm{S}_{\mathrm{a}}+\mathrm{S}_{\mathrm{g}}=(144+116) \mathrm{ft}=260 \mathrm{ft}$

\subsection{STABILITY ANALYSIS}

Stability margin equation: $\mathrm{S} . \mathrm{M}=\left(\mathrm{x}_{\mathrm{np}}-\mathrm{x}_{\mathrm{cg}}\right) / \mathrm{c}$. A small S.M. in the range of +5 to $+15 \%$ is desired make the UAV more maneuvering or responsive to elevator deflection. For calculating stability margin first need to calculate neutral point which was 3.26 in from the leading edge of the UAV. Then the aircraft static margin was calculated $26.5 \%$ (without payload) and $12.2 \%$ (with payload) calculated. The center of gravity (CG) needs to be placed close to the aerodynamic center (AC) and ahead of the vehicle neutral point for both empty weight and with payload for stability. The aircraft C.G. is $25.3 \%$ of chord from leading edge of wing for empty weight and is $39.5 \%$ of chord from leading edge of wing with payload along axis of aircraft on the plane of symmetry. The most forward point [2] of C.G of our aircraft is calculated 0.966 inch behind the leading edge after calculating the aerodynamic centre position of wing which is determined from the concept that change of moment w.r.t. AOA about A.C. is zero[3][5].

Table 5: Stability Parameters

\begin{tabular}{|c|c|c|c|c|c|c|c|c|c|}
\hline $\mathrm{Cl}_{\alpha, \mathrm{w}}$ & $\mathrm{C}_{\mathrm{La}, \mathrm{H}}$ & $\begin{array}{c}\overline{\mathrm{X}}_{\mathrm{ac}, \mathrm{w}} \text { (in) } \\
\text { (From } \\
\text { leading } \\
\text { edge of } \\
\text { wing }\end{array}$ & $\begin{array}{c}\overline{\mathrm{X}}_{\mathrm{ac}, \mathrm{H}} \text { (in) } \\
\text { (From } \\
\text { leading } \\
\text { edge of } \\
\text { wing }\end{array}$ & $\eta_{\mathrm{H}}$ & $\mathrm{S}_{\mathrm{H}} / \mathrm{S}$ & $\mathrm{d} \alpha_{\mathrm{H}} / \mathrm{d} \alpha$ & $\begin{array}{c}\overline{\mathrm{X}}_{\mathrm{np}} \text { (in) } \\
\text { (From } \\
\text { leading } \\
\text { edge of } \\
\text { wing) }\end{array}$ & $\begin{array}{c}\overline{\mathrm{X}}_{\mathrm{mf}} \text { (in) } \\
\text { (From } \\
\text { leading } \\
\text { edge of } \\
\text { wing) }\end{array}$ & $\begin{array}{c}\overline{\mathrm{X}}_{\mathrm{cg}}(\mathrm{in}) \\
\text { (From leading edge of } \\
\text { wing) } \\
\text { (Without payload) }\end{array}$ \\
\hline \hline 5.13 & 1.38 & 1.68 & 1.67 & 0.8 & 0.337 & 0.6 & 3.26 & 0.966 & 1.591 \\
\hline
\end{tabular}

\subsection{WEIGHT BUILD-UP ANALYSIS}

Basically To keep the aircraft stable the center of gravity $(\mathrm{CG})$ needs to be placed properly with respect to the neutral point. In the designed UAV CG was placed close to the aerodynamic center (AC) for both the empty weight and with payload. For most of the aircraft CG should be located between $25-30 \%$ of the chord length behind the leading edge. The calculated CG in the following table and it is realized that the CG is very close to the desired location. 
Table 6: Weight build-up

\begin{tabular}{|c|c|c|c|c|}
\hline $\begin{array}{l}\text { Total } \\
\text { mass(lb) }\end{array}$ & 1.404(without payload) & \multirow[t]{2}{*}{ Weight(lb) } & \multirow[t]{2}{*}{$\begin{array}{l}\text { Position in } \\
30 \% \text { chord }\end{array}$} & \multirow{2}{*}{$\begin{array}{lr}\text { Mass } & \text { Moment } \\
\text { about } & 30 \% \\
\text { chord } & \end{array}$} \\
\hline $\begin{array}{l}\text { Actual } \\
\text { CG(in) }\end{array}$ & $\begin{array}{l}1.591 \text { in(without payload from } \\
\text { wing leading edge) } \\
2.49 \text { in(with payload from wing } \\
\text { leading edge) }\end{array}$ & & & \\
\hline \multirow{5}{*}{$\begin{array}{l}\text { Electric } \\
\text { components }\end{array}$} & Motor & 0.196 & 8.0 & 1.568 \\
\hline & ESC & 0.066 & 3.7 & 0.2442 \\
\hline & Battery & 0.256 & 4.1 & 1.0496 \\
\hline & Receiver & 0.04 & -0.5 & -0.02 \\
\hline & Propeller & 0.026 & 9.5 & 0.247 \\
\hline Wing & $\begin{array}{l}\text { Wing, aileron servos, welds \& } \\
\text { hardware }\end{array}$ & 0.38 & -0.61 & -0.2318 \\
\hline Fuselage & $\begin{array}{l}\text { Fuselage, elevator \& rudder } \\
\text { servos, welds \& hardware }\end{array}$ & $\begin{array}{l}0.374 \text { (without payload) } \\
1.477 \text { (with payload) }\end{array}$ & $\begin{array}{l}-3.5 \\
-1.3\end{array}$ & $\begin{array}{l}-1.309 \\
-1.9201\end{array}$ \\
\hline \multirow[t]{2}{*}{ Empennage } & Vertical tail, welds \& hardware & 0.022 & -16.5 & -0.363 \\
\hline & Horizontal tail, welds \& hardware & 0.044 & -17.4 & -0.7656 \\
\hline \multicolumn{2}{|c|}{ Total mass(lb) } & $\begin{array}{l}\text { 1.404(without payload) } \\
2.51 \text { (with payload) }\end{array}$ & & $\begin{array}{l}0.4194 \text { (without } \\
\text { payload) } \\
-1.5(\text { with } \\
\text { payload) }\end{array}$ \\
\hline
\end{tabular}

\section{TESTING}

As mentioned earlier, different types of software test as well as physical hardware test was done before fabricating the UAV to find out suitable design which could meet desired objectives. The testing results are:

\subsection{WTT}

Wind tunnel testing was conducted in AF 100 Subsonic Wind Tunnel in the aerodynamics lab in MIST to determine the aerodynamic efficiency of wing to compare the experimental value with that theoretical analysis of historical data. The $\mathrm{C}_{\mathrm{L}(\max )}$ for NACA 4412 in the testing approximately equals the result of in JavaFoil and CFD. From the test it was also assured that NACA 4412 airfoil used perform a good aerodynamic efficiency during flight for the UAV.

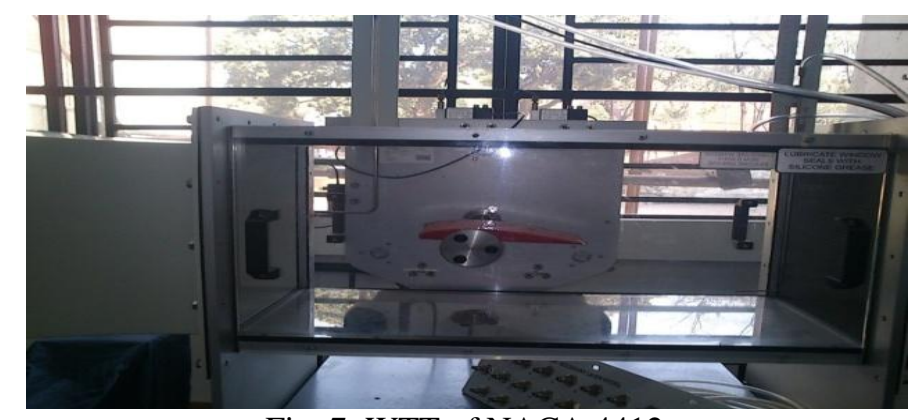

Fig. 7: WTT of NACA 4412

\subsection{CFD FLOW SIMULATION RESULTS}

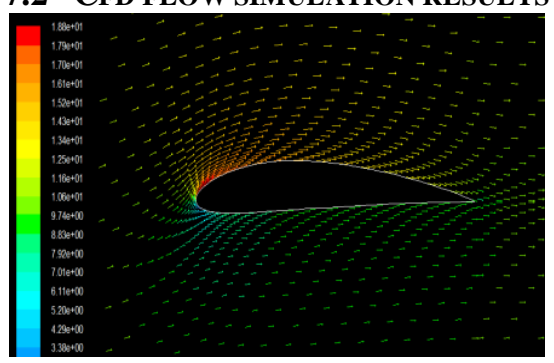

(a)

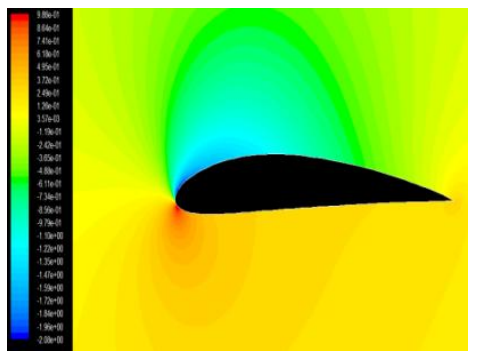

(b)

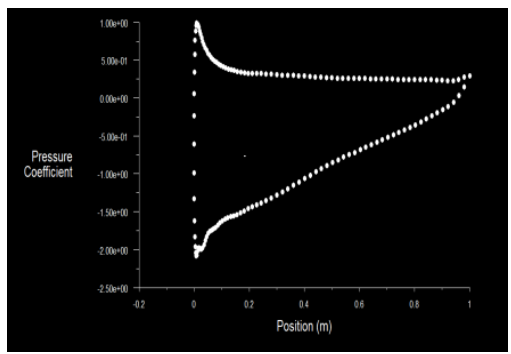

(c)

Fig. 8: plot of velocity vectors, $C_{P}$ Vs position graph \& pressure contours in FLUENT

As can be seen, the velocity of the upper surface is faster than the velocity on the lower surface. On the leading edge, a stagnation point is seen where the velocity of the flow is nearly zero. The fluid accelerates on the upper surface as can be seen from the change in colors of the vectors. On the trailing edge, the flow on the upper 
surface decelerates and converges with the flow on the lower surface. The lower curve of Fig. 8(c) is for the upper surface of the airfoil and has a negative pressure coefficient as the pressure is lower than the reference pressure. It is seen that there is a region of high pressure at the leading edge (stagnation point) and region of low pressure on the upper surface of airfoil. This is what we expected from analysis of velocity vector plot.

Table 7: Drag co-efficient calculation of NACA-4412 by CFD

\begin{tabular}{|c|c|c|c|c|c|c|}
\hline Zone name & $\begin{array}{c}\text { Pressure } \\
\text { force }(\mathrm{N})\end{array}$ & $\begin{array}{c}\text { Viscous } \\
\text { force }(\mathrm{N})\end{array}$ & Total force(N) & $\begin{array}{c}\text { Pressure } \\
\text { co-efficient }\end{array}$ & $\begin{array}{c}\text { Viscous } \\
\text { co-efficient }\end{array}$ & $\begin{array}{c}\text { Total } \\
\text { co-efficient }\end{array}$ \\
\hline \hline Airfoil & 0.2526493 & 0 & 0.2526493 & 0.0035888955 & 0 & 0.0035888955 \\
\hline \hline Net & 0.2526493 & 0 & 0.2526493 & 0.0035888955 & 0 & 0.00358889555 \\
\hline
\end{tabular}

Table 8: Lift co-efficient calculation of NACA-4412 by CFD

\begin{tabular}{|c|c|c|c|c|c|c|}
\hline Zone name & $\begin{array}{c}\text { Pressure } \\
\text { force(N) }\end{array}$ & $\begin{array}{c}\text { Viscous force } \\
(\mathrm{N})\end{array}$ & Total force(N) & $\begin{array}{c}\text { Pressure } \\
\text { co-efficient }\end{array}$ & $\begin{array}{c}\text { Viscous } \\
\text { co-efficient }\end{array}$ & $\begin{array}{c}\text { Total } \\
\text { co-efficient }\end{array}$ \\
\hline \hline Airfoil & 86.163106 & 0 & 86.163106 & 1.2239511 & 0 & 1.2239511 \\
\hline \hline Net & 86.163106 & 0 & 86.163106 & 1.2239511 & 0 & 1.2239511 \\
\hline
\end{tabular}

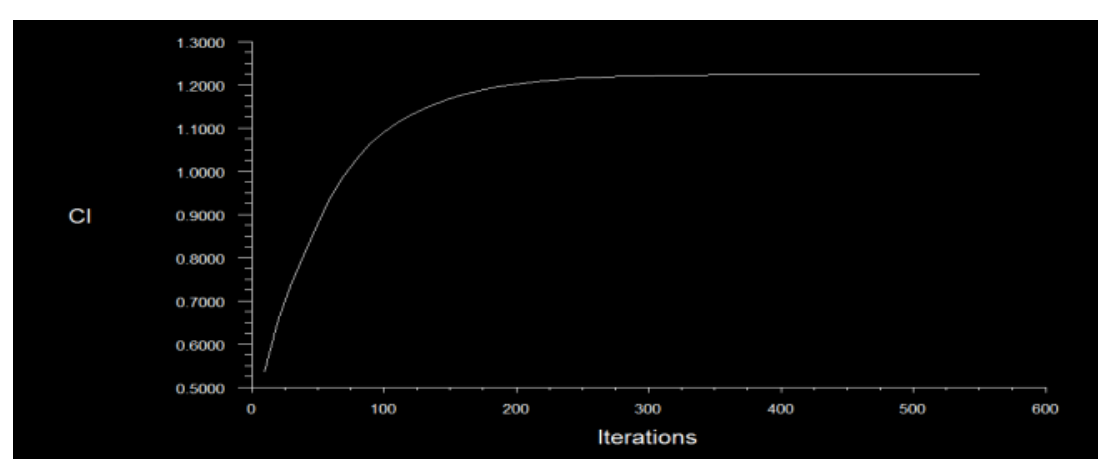

Fig. 9: $\mathrm{C}_{1}$ value determination in $\mathrm{CFD}$

\subsection{STRUCTURAL TEST}

Testing was conducted to verify that XPS foam has the strength to perform the desired property. Tension testing performed on the tension test machines at SM Lab in MIST and it was confirmed from the tested technical data that the structure will not fail in air. From stress strain plot of the XPS it was verified that the elastic limit can sustain up to 0.02 strain limit with corresponding stresses of $35 \mathrm{psi}$.

During take-off lift must be greater than weight. On the basis of this principle wing load testing is obligatory. The wing tip is set at two ends \& weighed down with some load at the centre of wing. The wing was totally broken down after placing $3.3 \mathrm{lb}$ on the wing. So, the maximum bending moment the UAV can sustain is $5.5 \mathrm{lb}-\mathrm{ft}$.

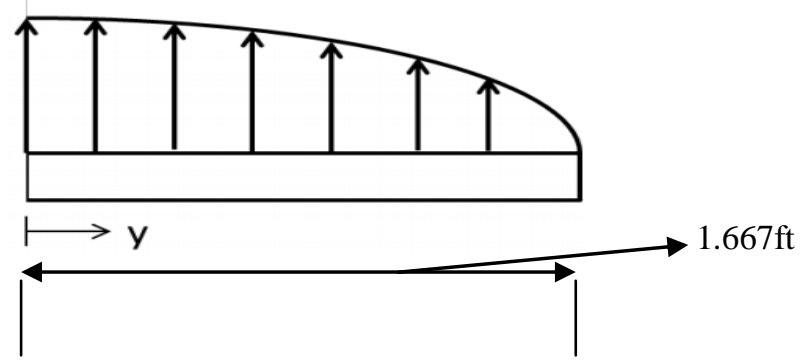

Fig. 10: elliptical loading over the wing semi span

The maximum stress in such a beam is at the wing root. Since elliptical loading was assumed, so we first computed the lift per unit span at the root of the wing. This was done by integrating the lift distribution and setting the value equal to half the desired weight of the plane with payload. This gave a lift per unit span at the wing root of $13.77 \mathrm{~N} / \mathrm{m}$ from the following eqn: $\quad \int_{0}^{b / 2} L \sqrt{ }\left\{1-(2 y / b)^{\wedge} 2\right\} d y=W / 2$

\subsection{Flight TEST}

Many flight tests conducted through a long time from January to April 2013 and then achieved the highest performance design to successfully participate in the competition. Followings were the flight testing results: 


\begin{tabular}{|c|c|c|}
\hline $\begin{array}{l}\text { Flight Testing } \\
\text { Schedule }\end{array}$ & Purpose & Consequences \\
\hline $03-01-13$ & To check the ability to fly & Unairworthy \\
\hline $16-01-13$ & To check the hand launching take-off & Conducted takeoff safely \\
\hline $29-01-13$ & To check the responding of the control system & Rapid response \\
\hline $01-02-13$ & To test the stability performance & Unstable \\
\hline $07-02-13$ & To test the capability of safe landing & Crashed before landing \\
\hline $13-02-13$ & To check the control surface deflection & Assured \\
\hline $26-02-13$ & Get a hold of safe landing & Safe landing \\
\hline $08-03-13$ & To check the maneuverability during $180^{\circ}$ turn & Successfully maneuvered \\
\hline $15-03-13$ & $\begin{array}{l}\text { Verify the behavior of aircraft during flight with payload as per } \\
\text { competition missions requirements }\end{array}$ & $\begin{array}{l}\text { Had enough static margin as } \\
\text { mission desired }\end{array}$ \\
\hline $27-03-13$ & $\begin{array}{l}\text { To scrutinize the aircraft stability(whether the c.g. position } \\
\text { changed or unaffected) }\end{array}$ & $\begin{array}{l}\text { c.g. position not too much change } \\
\text { with varying payload }\end{array}$ \\
\hline
\end{tabular}

\section{AVIONICS}

The avionics control system of UAV relates to mainly controlling the craft on air which mainly includes navigation, IMU sensor, GPS units, flight management, altimeters, servos etc. The servos used to design the UAV are having: dimension $0.86 \times 0.4 \times 0.79 \mathrm{in}$; operating voltage $4.8 \mathrm{~V}$; stall Torque $0.6 \mathrm{~kg} / \mathrm{cm}$ and speed $0.1 \mathrm{sec} / 60$ degree.

Single battery system with battery eliminator circuits used with a red shunt plug was positioned between the ESC and motor. Lithium Polymer battery was used as the power supply because they worked well and hold a large amount of current which was lighter than nickel metal and Ni-Cad batteries. The used Li-Po battery can supply $11.1 \mathrm{~V}$ and a current rating of $1350 \mathrm{mAh}$. 3 cells Li-Po was used which weighted $115 \mathrm{gm}$ in total. Using 3 cells was advantageous as it was not to allow the battery voltage to drop too low. Using 3 cells lithium polymer it was recommended to land the UAV when the voltage rating drops to $9 \mathrm{~V}$. Features of the battery were: Cell Voltage: 3.6-3.7V (nominal), 3cells making 11.1V; Capacity: 1350mAh; Energy by Weight : $120 \mathrm{Wh} / \mathrm{L}$; Energy by Volume: $250 \mathrm{Wh} / \mathrm{L}$; Discharge characteristics: $35 \mathrm{C}$; Temperature range: $-20^{\circ} \mathrm{C}$ to $+60^{\circ} \mathrm{C}$; Preferred Charge Methods: Constant Current/ Constant Voltage

The ESC used in the UAV operated at a Current Rating of 3A. The communication and navigation system consisted of a transmitter and a receiver which operated based on the transmission and reception of radio frequencies [8]. By this system the control surface movement and RPM was controlled from the ground. A receiver was kept in UAV which received RF signals, modulate the signal and sent command to the control surfaces and motor according to instruction given from the ground. For communication system the used transmitter was FS-TH9X $2.4 \mathrm{GHz} 9 \mathrm{CH}$ which operated at $2.4 \mathrm{GHz}$ frequency. As the transmitter module had 9 channels so 9 different commands could be sent at a time. Features of transmitter module: Channels: 9 channels TH9X; Model type: Helicopter, Airplane and Glider; RF Power: Less than 20db; Modulation: GFSK; Code type: PPM/PCM; Sensitivity: 1024; LCD type: 128*64 dot; Low voltage warning: Yes; DSC port: Yes; Charge port: Yes; Power: 12VDC; Weight: 680gm.

\subsection{CONTROL SYSTEM}

The pilot controls the aircraft by remote during flight according to the following block diagram:

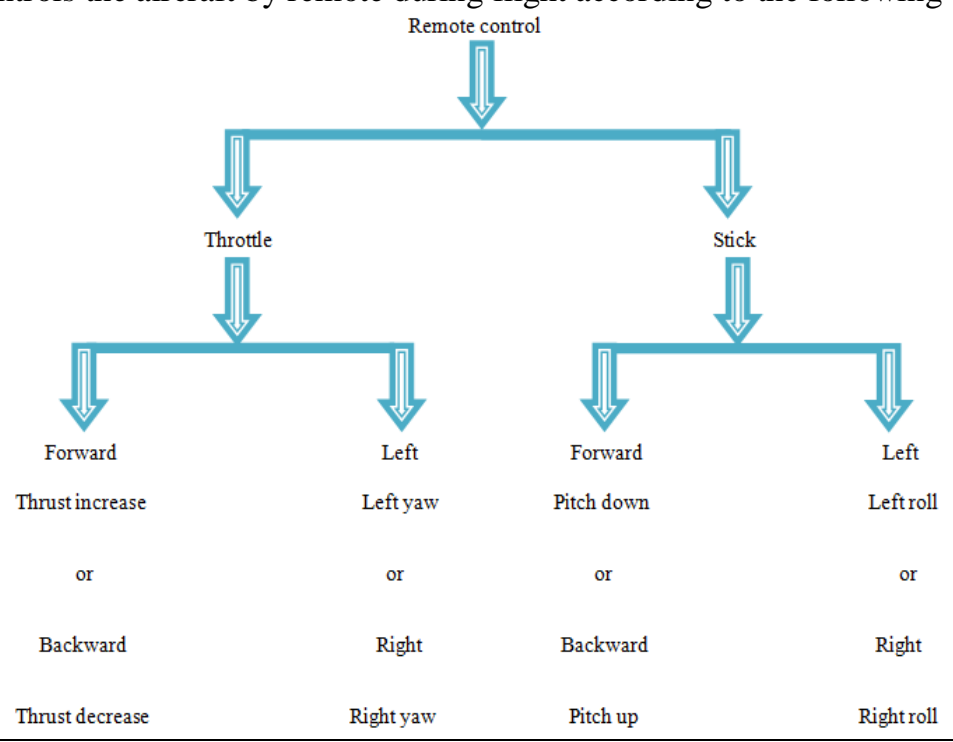




\subsection{OPERATION CYCLE}

During the competition the operation cycle was given through which the aircraft must fly with safe landing for scoring. There was two option of operation cycle. The team took option 1 which is shown in the following Fig. 11. Once takeoff occurs, it was necessary for aircraft in airborne and fly past a first cone before turning approximately 180 degrees in heading, fly past a second cone \& turning another 180 degrees in opposite direction of previous one and lands. Takeoff must be done from a semicircular launching zone measuring 10 feet in radius.

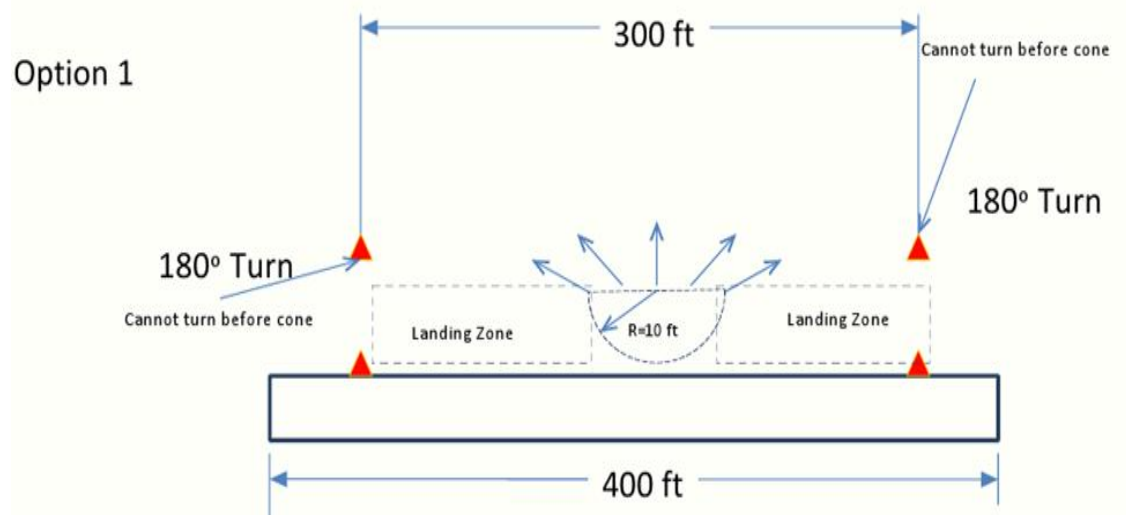

Fig. 11: operational area in the competition

IX. FinANCIAL ASSESMENT

It was one of the major aims to manufacture the UAV with minimum cost beside the unique design requirement and the project team was successful with that desired. The cost for different parts of the UAV in the following table:

Table 10: Financial cost in the project

\begin{tabular}{|c|c|}
\hline ITEM & COST \\
\hline Motor(1200Kv) & $\$ 16$ \\
\hline \hline ESC & $\$ 10$ \\
\hline \hline Servo(4) & $\$ 15$ \\
\hline \hline Battery(11.1V, 1350 mAh) & $\$ 40$ \\
\hline \hline Connector & $\$ 2$ \\
\hline Wire, Cable & $\$ 1$ \\
\hline \hline Remote(Transmitter \& Receiver) & $\$ 90$ \\
\hline \hline XPS(Polystyrene) Foam & $\$ 6$ per piece \\
\hline \hline Depron Foam & $\$ 1.2$ per piece \\
\hline Filament tape & $\$ 5$ \\
\hline Plywood & $\$ 2$ \\
\hline Push rod & $\$ 2$ \\
\hline
\end{tabular}

\section{CONCLUSION}

The aircraft was conceptualized under a set of design requirements. However the conceptual design converted into a real aircraft with preliminary design and detail design processes [6] with the series of limitation as discussed. The design approach gave the right way to apply practical knowledge in real life application. Basically the main aim was to fly the UAV with heavy payload for good scoring. Beside this aim the team tried to keep the cost as low as possible which is the main target for the engineers now-a-days. There was a great problem the team faced with the unavailability of the manufacturing material and electric components in local market. These unavailable things were taken from Singapore. Through a systematic procedure finally the aircraft was manufactured and then launched in the sky for a series of flight tests. After facing many problems through a long time (almost 2 months) the final design was manufactured for the competition. The final launching was done successfully at the competition site (12-14 April) of SAE Aero Design Competition at California, USA. The following figure is the successful flight in the competition. This had been a unique experience of the project group in conceptualizing, designing, fabricating and finally participating and qualifying in international competition with a good scoring, thereby making a history in Bangladesh and MIST in particular. 


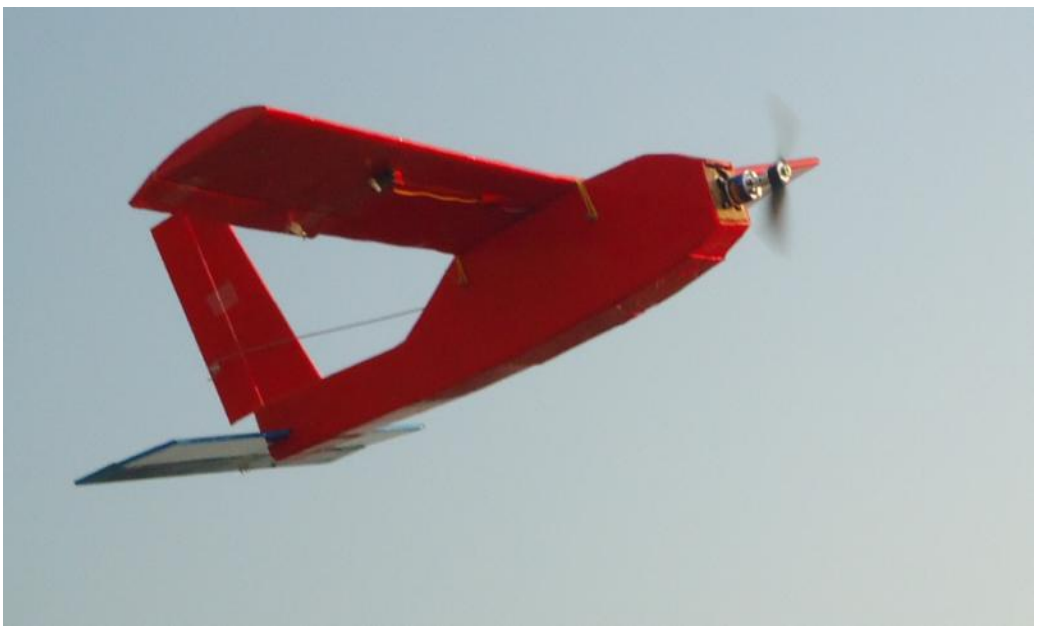

Fig. 12: successful flight of the UAV

\section{REFERENCES}

[1] John D Anderson Jr., Introduction to flight (7 West Patel Nagar, New Delhi, Tata McGraw-Hill Publishing Company Limited, Fifth edition).

[2] L J Clancy. Aerodynamics (Melborne, Pitman Publishing Limited)

[3] Kermode, Mechanics of flight (Hong Kong, Pearson Education Limited, 2006)

[4] John D. Anderson, Jr. Fundamentals of aerodynamics (1221 Avenue of the Americas, New York, McGraw-Hill, $3^{\text {rd }}$ edition)

[5] John D. Anderson, Jr. Aircraft performance and design (7 West Patel Nagar, New Delhi, Tata McGraw-Hill Education Private Limited, Fifth edition)

[6] Daniel P Raymer. Aircraft Design: a conceptual approach (Washington D.C., American Institute of Aeronautics and Astronautics, Inc.)

[7] Jonathan How, Ellis King and Yoshiaki Kuwata, Flight Demonstrations of Cooperative Control for UAV Teams, AIAA 3rd "Unmanned Unlimited" Technical Conference, Workshop and Exhibit. Chicago, Illinois, September 2004.

[8] HaiYang Chao, YongCan Cao and YangQuan Chen, Autopilots for Small Unmanned Aerial Vehicles: A Survey, International Journal of Control, Automation, and Systems, 8(1), 2010, 36-44.

[9] Selcuk Bayraktar, Georgios E. Fainekos and George J. Pappas, Experimental Cooperative Control of Fixed-Wing Unmanned Aerial Vehicles, 43rd IEEE Conference on Decision and Control, Atlantis, Paradise Island, Bahamas, December, 2004.

[10] Lee Nicholai's White Paper (students.sae.org/competitions/aerodesign/rules/aero_nicolai.doc)

[11] UIUC Airfoil Coordinate Database. (http://www.ae.uiuc.edu/mselig/ads/coord_database.html) 